AGRICA: Journal of Sustainable Dryland Agriculture, 12 (2): 131-136 (2019)

ISSN-Online : 2715-4955; ISSN-Cetak: 2715-6613

DOI: https://doi.org/10.37478/agr.v12i2.307

\title{
PENGARUH LAMA PENGUKUSAN TERHADAP KUALITAS KERUPUK SINGKONG DENGAN BAHAN DASAR TEPUNG CASAVA
}

\author{
Yuyun Wahyuni \\ Fakultas Pertanian, Universitas Nusa Nipa Maumere \\ Email : uyung210683@yahoo.co.id
}

\begin{abstract}
Effect of old steaming on quality of cassarrock crups with basic materials of casava flour. Cassava is also known as cassava, an annual tropical and sub-tropical tree from the Euphorbiaceae family. Tubers widely recognized as staple foods. Cassava has advantages compared to other food ingredients. Aside from being a staple food, many kinds of cassava processed products have utilized by our community, including cassava crackers. This study used a Completely Randomized Design (CRD) with 5 (five) treatments and 4 (four) replications or $5 \times 4$ to obtain 20 experimental units. The treatment factor is steaming length, which consists of 5 levels of steaming time as follows: A: 30 minutes, B: 60 minutes, C: 90 minutes, D: 120 minutes, E: 150 minutes. The quality of cassava crackers to be tested or measured based on their physical appearance is related to consumer acceptance. In conducting organoleptic testing, panelists influenced by several factors. Factors that influence panelists include physical factors and psychological factors. The organoleptic parameters observed included color, taste, and degree of crispness. Laboratory tests include carbohydrate tests, water content, ash content, protein, and fat content. The conclusion was that the effect of steaming time had no significant effect on moisture content, ash content, protein, and crispness, while the effect of steaming duration had a significant impact on the levels of fat, carbohydrate, taste, and color in cassava crackers. The best quality of the five treatments was treatment 5 (p5), ie, steaming time with 150 minutes
\end{abstract}

Keywords : Cassava, Flour, Kracker, Steaming

\section{PENDAHULUAN}

Ubi kayu (Manihot esculenta) merupakan sumber bahan makanan ketiga di Indonesia setelah padi dan jagung. Dengan perkembangan teknologi, ubi kayu dijadikan bahan dasar pada industri makanan seperti sumber utama pembuatan pati. Selama ini produksi ubi kayu yang berlimpah sebagian besar digunakan sebagai bahan baku industri tapioka.
Ubikayu mempunyai banyak variasi untuk dapat dibuat sebagai bahan pangan atau bentuk lain. Dalam ubikayu segar mengandung beberapa nutrisi penting, diantaranya kandungan kalori, kandungan karbohidrat, dan berat yang dapat dikonsumsi. Ubikayu mempunyai kegunaan luas dalam industri non pangan, termasuk produk seperti gaplek, chips, pellet dan tepung tapioka. Pengembangan 
industri ubikayu dapat melalui berbagai proses, seperti proses dehidrasi, gaplek, chips, pellet, dan tapioka.

Kerupuk singkong merupakan salah satu alternatif olahan pangan yang menyehatkan (healthy foods). Selain itu kerupuk singkong mentah memiliki umur simpan yang relatif lama sampai berbulanbulan, sebelum di goreng untuk di konsumsi, sehingga mempunyai prospek ekonomi yang bagus.

Provinsi NTT merupakan salah satu sentra penghasil ubikayu. Di Kabupaten Sikka budidaya ubikayu menggunakan bahan tanam berasal dari berbagai klon ubikayu, baik klon unggul yang telah dilepas secara nasional maupun klon-klon lokal yang sekiranya masih menghasilkan produksi cukup tinggi dan disenangi petani. Di Kabupaten Sikka budidaya ubikayu merupakan usaha yang bersifat turun temurun dan sudah mendarah daging bagi petani. Penelitian ini bertujuan untuk mengetahui lama pengukusan yang sesuai sehingga dapat memberikan kualitas kerupuk singkong yang baik.

\section{BAHAN DAN METODE}

Penelitian ini dilaksanakan di Laboratorium Fakultas Pertanian Universitas Nusa Nipa Maumere. Untuk uji organoleptik dilasanakan di Laboratorium Fakultas Pertanian Universitas Nusa Nipa sedangkan untuk analisis kimia dilaksanakan di Laboratorium Politeknik Kupang.

Penelitian ini menggunakan Rancangan Acak Lengkap ( RAL ) dengan
5 ( lima ) perlakuan dan 4 ( empat ) ulangan atau 5 x 4 sehingga diperoleh 20 unit percobaan. Variabel yang diukur ada dua yaitu Uji Sensori yang meliputi warna, rasa dan tingkat kerenyahan. Sedangkan variabel kedua adalah Analisis Proksimat yang meliputi uji karbohidrat ( AOAC 2005), kadar air (AOAC 2005kadar abu (AOAC 2005), protein (AOAC 2005) dan kadar lemak (AOAC 2005).

\section{ANALISIS DATA}

Data yang diperoleh dianalisis dengan menggunakan metode deskriptif yaitu menggambarkan, mentabulasikan dan menjelaskan tentang karakteristik kerupuk mulai dari penghitungan kadar air, kadar abu, kadar lemak, kadar protein, kadar karbohidrat dan sensoris kerupuk.

\section{HASIL DAN PEMBAHASAN \\ Kadar Air}

Kadar air merupakan jumlah air yang terkandung dalam bahan pangan. Kadar air merupakan karakteristik yang sangat penting pada bahan pangan, karena air dapat mempengaruhi penampakan, tekstur, dan cita rasa pada bahan pangan (Winarno, 2008). Rata-rata kadar air pada kerupuk singkong $\mathrm{P} 1:$ 4,86\%, P2 : 5,41, P3 : 6,05, P4 : 4,90, P5 : 4,81. Didalam perlakuan tersebut tidak terdapat perbedaan yang sangat nyata pada taraf kepercayaan $5 \%$. Akan tetapi Kadar air kerupuk yang diperoleh pada setiap perlakuan pengukusan memenuhi SNI 012713-2009 yang mencantumkan kadar air maksimum kerupuk sebesar $11 \%$. 
Penentuan kadar air dapat dilakukan dengan beberapa cara. Hal ini tergantung pada sifat bahannya. Pada umumnya penentuan kadar air dilakukan dengan mengeringkan bahan dalam suhu 105 hingga 110 derajat selama 3 jam atau sampai didapat berat yang konstan. Selisih berat sebelum dan sesudah pengeringan adalah banyaknya air yang diuapkan (Winarno, 2008). Kadar air dalam bahan pangan ikut menentukan kesegaran dan daya awet bahan pangan tersebut, kadar air yang tinggi mengakibatkan mudahnya bakteri, kapang dan khamir untuk berkembang biak sehingga akan terjadi perubahan pada bahan pangan yang dapat mempercepat pembusukan (Winarno 2008).

\section{Kadar Abu}

Kadar abu berhubungan dengan mineral suatu bahan. (Sudarmadji, 1989). Bahan pangan terdiri dari $96 \%$ bahan anorganik dan air, sedangkan sisanya merupakan unsur-unsur mineral. Bahanbahan organik dalam proses pembakaran akan terbakar tetapi komponen anorganiknya tidak, karena itulah disebut sebagai kadar abu (Sudarmadji, 1989). Kadar mineral dalam bahan pangan mempengaruhi sifat fisik bahan pangan serta keberadaannya dalam jumlah tertentu mampu menghambat pertumbuhan mikroorganisme jenis tertentu (Suhartini, 2012).

Rata-rata kadar abu pada kerupuk singkong P1 : 3,85, P2 : 4,10, P3 : 4,10, P4 : 3,80, P5 : 4,15. Didalam perlakuan tersebut tidak terdapat perbedaan yang sangat nyata pada taraf kepercayaan $5 \%$.
Kadar abu yang diperoleh dari masingmasing perlakuan berkisar antara 3,80 4,15, sedangkan SNI 01- 2713-2009 mensyaratkan kadar abu tanpa garam yang diijinkan adalah sebesar $1 \%$. Penentuan kadar abu total dapat digunakan untuk berbagai tujuan diantaranya untuk menentukan baik tidaknya suatu proses pengolahan, untuk mengetahui jenis bahan yang digunakan, serta penentuan abu total sangat berguna sebagai parameter nilai gizi bahan makanan (Sudarmaji, 2003).

\section{Kadar Protein}

Protein adalah sumber asam amino yang mengandung unsur-unsur $\mathrm{C}, \mathrm{H}, \mathrm{O}$, dan $\mathrm{N}$ yang tidak dimiliki oleh lemak atau karbohidrat (Winarno 2008). Kandungan Protein dalam setiap bahan makanan berbeda kadar dan jenisnya. Protein dalam susunan pangan pada waktu dicernakan dirombak menjadi asam amino. Hampir dua puluh asam amino diketahui terdapat dalam tubuh dan dalam protein pangan (Sudarmaji, 2003).

Rata-rata kadar abu pada kerupuk singkong P1 : 1,46, P2 : 1,50, P3 : 1,52, P4 : 1,58, P5 : 1.77. Didalam perlakuan tersebut tidak terdapat perbedaan yang sangat nyata pada taraf kepercayaan $5 \%$. Hasil analisis protein menunjukkan bahwa kerupuk tidak memenuhi batas minimal kadar protein pada SNI 01-2713-2009 yaitu sebesar 6\%. Kandungan protein yang di bawah standart dari SNI ini dikarenakan dalam pembuatan kerupuk singkong tidak menambahkan bahan pengikat seperti tepung tapioka, hal iniah yang menyebabkan kandungan protein pada kerupuk tersebut sangat kecil. 


\section{Kadar Lemak}

Lemak merupakan bahan padat pada suhu ruang disebabkan kandungannya yang tinggi akan asam lemak jenuh yang tidak memiliki ikatan rangkap, sehingga mempunyai titik lebur yang lebih tinggi, sedangkan minyak merupakan bahan cair pada suhu ruang disebabkan tingginya kandungan asam lemak yang tidak jenuh, yang memiliki satu atau lebih ikatan rangkap diantara atom-atom karbonnya, sehingga mempunyai titik lebur yang rendah (Winarno, 2008). Lemak terdapat pada pada hampir semua bahan pangan dengan kandungan yang berbeda-beda. Tetapi lemak seringkali ditambahkan dengan sengaja kebahan makanan dengan berbagai tujuaan selain itu lemak juga merupakan sumber energi yang lebih efektif dibanding karbohidrat dan protein (Winarno, 2008).

Rata-rata kadar lemak pada kerupuk singkong P1 : 17,17, P2 : 16,30, P3 : 17,56, P4 : 18,64, P5 : 15,58. Didalam perlakuan tersebut terdapat perbedaan yang sangat nyata pada taraf kepercayaan $5 \%$. Lemak yang terkandung dalam kerupuk dapat mempengaruhi daya kembang pada produk kerupuk yang dihasilkan, karena sebagian komponen lemak diadsorbsi untuk membentuk lapisan lemak pada permukaan granula sehingga penetrasi air pada proses gelatinisasi terganggu.

\section{Karbohidrat}

Karbohidrat pada produk olahan makanan mempunyai peran yang sangat penting dibandingkan dengan syarat yang lainnya seperti protein, vitamin, tekstur didalam menentukan apakah produk tersebut di jual atau tidak. Karbohidrat juga mempunyai peranan dalam menentukan karakteristik bahan makanan misalnya rasa, warna, tekstur, dan lainnya (Sudarmaji, 2003).

Rata-rata karbohidrat pada kerupuk singkong P1 : 77,53, P2 : 78,10, P3 : 76,90, P4 : 75,97, P5 : 78,91. Didalam perlakuan tersebut terdapat perbedaan yang sangat nyata pada taraf kepercayaan $5 \%$.

Rasa

Rasa pada produk makanan mempunyai peran yang sangat penting dibandingkan dengan syarat yang lain misalnya aroma, warna dan tekstur dalam menentukan produk olahan tersebut laku dijual atau tidak di tingkat konsumen. Hasil analisis of variance (ANOVA) menunjukan bahwa hasil pengamatan uji organoleptik rasa (\%) dari kerupuk singkong antara perlakuan P1 : 2,0250, P2 : 2,2, P3 : 2,3125, P4 : 2,5875, P5 : 2,5625 berbeda nyata. Didalam perlakuan tersebut terdapat perbedaan yang sangat nyata pada taraf kepercayaan $5 \%$.

Berbagai senyawa kimia menimbulkan rasa yang berbeda, Suhu akan mempengaruhi kemampuan kuncup cecapan untuk menangkap rangsangan rasa, lalu pada konsentrasi setiap orang mempunyai batas konsentrasi terendah terhadap suatu rasa agar masih bisa dirasakan, sedangkan interaksi dengan komponen rasa yang lain akan berinteraksi dengan komponen rasa primer. Akibat yang ditimbulkan mungkin 
peningkatan atau penurunan intensitas rasa.

\section{Warna}

Warna merupakan salah satu kriteria yang sangat menentukan daya terima suatu bahan makanan, Sebab warna menentukan kenampakan dari suatu produk. suatu bahan yang dinilai sangat bergizi, enak dan teksturnya sangat baik tidak akan dimakan apabila warna yang memberikan kesan telah menyimpang dari warna yang seharusnya (Winarno, 2007).

Hasil analisis of variance (ANOVA) menunjukan bahwa hasil pengamatan uji organoleptik warna (\%) dari kerupuk singkong antara perlakuan P1 : 1,69, P2 : 2,075, P3 : 2,325, P4 : 2,125, P5 : 2,48 berbeda nyata. didalam perlakuan tersebut tidak terdapat perbedaan yang sangat nyata pada taraf kepercayaan $5 \%$. Suatu bahan yang dinilai bergizi, enak, dan teksturnya sangat baik tidak akan dimakan apabila memiliki warna yang tidak sedap dipandang atau memberi kesan telah menyimpang dari warna yang seharusnya. Penerimaan warna suatu bahan berbedabeda tergantung faktor alam, geografis dan aspek sosial masyarakat penerima (Winarno, 2007).

\section{Kerenyahan}

Kerenyahan kerupuk sangat ditentukan oleh kadar airnya. Semakin banyak kerupuk tersebut mengandung air, maka kerupuk akan semakin kurang renyah (Soemarmo, 2001). Hasil analisis of variance (ANOVA) menunjukan bahwa hasil pengamatan uji organoleptik tingkat kerenyahan (\%) dari kerupuk singkong antara perlakuan $\mathrm{P} 1: 2,26, \mathrm{P} 2: 2,47, \mathrm{P} 3$ : 2,66, P4 : 2,58, P5 : 2,65 tidak berbeda nyata. Didalam perlakuan tersebut tidak terdapat perbedaan yang sangat nyata pada taraf kepercayaan $5 \%$. Faktor $\mathrm{pH}$ pada pati juga dapa mempengaruhi mutu produk berbahan dasar pati. Tekstur yang kurang gurih dapat disebabkan pada saat penggorengan maupun bentuk serta tingkat ketebalan keerupuk pada proses pengirisan.

\section{KESIMPULAN}

Pengaruh lama pengukusan tidak berpengaruh nyata pada kadar air, kadar abu, protein, dan kerenyahan sedangkan pengaruh lama pengukusan yang berpengaruh nyata yaitu pada kadar lemak, karbohidrat, rasa, dan warna pada kerupuk singkong. Mutu yang terbaik dari ke lima perlakuan adalah pada perlakuan 5 (p5) yaitu lama pengukusan dengan waktu 150 menit dengan nilai uji kadar protein 1.77, nilai kadar abu 4.15, nilai karbohidrat 78.91 dan nilai uji warna 2.48, sedangkan mutu terendah terdapat pada perlakuan 1 (p1) dengan lama pengukusan 30 menit dengan nilai uji protein 1.46, nilai uji rasa 2.02, nilai uji warna 1,69 dan nilai uji kerenyahan 2.2.6.

\section{UCAPAN TERIMA KASIH}

Pada kesempatan ini penulis ingin mengucapkan terima kasih kepada semua pihak yang telah membantu dengan caranya masing-masing dalam melengkapi tulisan ini. 
AGRICA, VOL. 12, NO. 2 (2019)

\section{REFERENSI}

AOAC, 2005. Official Methods of Analysis. Association of Official. Analytical Chemists. Benjamin Franklin Station, Washington.

Sudarmaji S, Haryono B, Suhardi. 1989.

Prosedur Analisa untuk Bahan Makanan dan Pertanian. Yogakarta: Liberty.

Sudarmaji, Suhardi. 2003. Prosedur analisa untuk analisa bahan makanan dan Pertanian. Liberty : Yogyakarta

Suhartini, Astuti. 2012. Pengetahuan Bahan Untuk Industri Pertanian. PT.Mediyatama Sarana Perkasa: Jakarta

Soemarno. 2005. Pangan, Gizi dan Pertanian. Penerbit Universitas Indonesia : Jakarta

Winarno, F.G. 2007. Teknologi Pangan. PT.GRAMEDIA : Jakarta

Winarno, F.G. 2008. Kimia Pangan dan Gizi. PT.GRAMEDIA : Jakarta 